\title{
My Front Row Seat Memoir VI
}

\section{Further Encounters at The Greatest Show on Earth}

\author{
MORE ON 65 YEARS IN MEDICINE
}

\author{
Henry J.M. Barnett
}

Can. J. Neurol. Sci. 2011; 38: 417-421

The memories that follow will largely concern people and events from the many lands that I was privileged to visit, mainly because they were involved with one of my Trials or by invitations to address meetings or rounds.

Central America remains part of the "Developing World". The country of Panama when we first visited was still partly an American colony so that USA could keep control of the great canal. We passed through there in October 1963 because the first meeting of the Pan-American Neurological Congress was to take place in Lima, Peru. It was chaired by Oscar Trelles, a gifted neurologist whom I first met when he was visiting Queen Square. By 1963 he was the Prime Minister of his country. En route to Peru, Kay and I planned a three-day stop-over in Panama City. A routine dental filling had been done a few days before we left and at the fuel-stop in Miami I had a toothache. It reached unbearable and untouchable proportions (including chewing) by Panama. I phoned the office of the British ambassador and his secretary advised that a Philadelphia-trained dentist, Pedro Brin, was highly regarded by her boss. He said it was to come out now or we must stay two or three days to complete a root canal. "It's a 'dry socket' precipitated by altitude change." For ten balboa, I called Jim Purvis, my Toronto dentist, and under the circumstances he advised extraction of the offending brute. One hour later most of the pain and all of the molar were memories as was another ten balboa (about $\$ 10$, Brin's fee). Friendly handshakes and smiles all around concluded the visit. At that time he obviously did not believe that medical or dental professionals should be competing with present-day hockey or soccer players or those deciding upon the bonuses in the head offices of bankrupt banks.

In Panama we drove as far south as the Pan America Highway went. We felt that we were in unfriendly country as dusk appeared, but were intrigued and distracted by a sky alive with fruit-bats (flying foxes). I do not know if they are part of the local diet as they are in Guam. Their bodies are about the size of an Ontario rabbit and their wing-span that of a small heron.

There has always been sufficient mistrust between Panama and Colombia that the Trans-America Highway was never completed and it reverts to a game-trail. We turned about. Like too many parts of the world where one could once go with reasonable impunity, many have become so dangerous that passing through may be foolhardy because of drug traffickers and so-called "terrorists" combating military despots. There is still no paved Highway connecting all continental countries of the New World, nor can one travel with impunity the millennium-old Silk Route travelled and described by Marco Polo. The Orient Express, made famous by Agatha Christie, was still travelled by people in the 1950s and 60's, but is now a risky venture. Despots and addicts have shrunk our world.

On our last day in Panama in a rented car we had breakfast on the Pacific coast then drove to Colon (Columbus' landing site on his fourth and last crossing in 1502-1504). Lunch was taken beside the Atlantic Ocean. Much of our route was alongside the great canal. Within sight of this scientific and engineering marvel (yellow fever and malaria now being preventable), local farmers could be seen ploughing on foot behind oxen yoked together. In front of a couple of humble dwellings small girls (age 10-12) were observed grinding flour from manioc (cassava) roots in mortars of large hollowed logs using pestles carved from heavy pieces of hardwood almost as tall as their small selves. How much better that they lived out their childhood days with skipping ropes, hoola hoops and field-hockey sticks! As in the Amazon jungles (ahead) the contrasts were great. In this case colonialism was again a one-way street.

At one point on this excursion we overlooked a check-point between the American and the local jurisdiction. In response to a loud siren and flashing red lights we turned about, wondering what to expect. We were approached by a sergeant with a clipboard and fair English: "A Hertz car, what state are you from?" "Canada?" "In that case maybe you would like to buy a ticket on our National Lottery?" Twenty balboa later and without even being asked for passports we were dismissed. We drove off all smiles again and heard no more, certainly no phone message saying that we had won 500,000 balboa. I reflected that I never buy lottery tickets but I make an exception at gunpoint!

Colon had a statue of Christopher Columbus and little else of remembered interest. It rained very hard and luckily the third mechanic we visited finally determined that our windshieldwipers would work when he changed the fuse. The route is mountainous and it pounded rain from the Atlantic to the Pacific but we had a plane to catch at dawn for Lima through Cali. Security at the Colombian airfield was sufficiently lax that we

Received SePtember 27, 2010. Final Revisions Submitted February 28, 2011. Correspondence to: Henry J.M. Barnett, Suite 701, 305 Balliol St., Toronto, Ontario, M4S 3H5, Canada. 
had to circle once while a woman with customary shawl and a stick drove her cow across the tarmac.

In Lima Peru, the Cocktail Reception was several hours late as we awaited the PM's arrival. In time we learned that urgent discussions with a politically powerful group of peasants occupied Trelles' time. While waiting, Kay and I had more Pisco Sours than we really needed, but they consoled my jaw, which had lost its Panama freezing. Several months later, Time magazine reported that a coup in Peru had tossed Trelles out of office. The reason given by those who took over was that he was too lenient with those lesser forms demanding land reform. It is my understanding that some of these dissatisfied peasants metamorphosed into the terrorist group, The Shining Path. As America, Ireland, South Africa, Sri Lanka and Palestine have taught us, there is swampy ground on the path dividing loyalty as distinct from treason by seemingly forlorn and at times overly violent resistance to justifiable change.

The Congress was not a spell-binder: a curious mixture of case reports, small personal case series and repetitious dogma. The Harvard-located former Queen Square doyen, DennyBrown put my blood-pressure up by telling me in a group of colleagues that our new Department of Clinical Neurosciences was a misnomer. "After all, it has only a basis in clinical work and that cannot be dignified as 'neuroscience'." Despite DennyBrown's skepticism, clinical study can impact on disease control just as certainly as laboratory breakthroughs. Some of the best examples of this came from the renowned Harvard associates of Denny-Brown: Ray Adams, Miller Fisher, JP Mohr and Lou Caplan.

My own talk was on the pathogenesis of syringomyelia and caused angst to some of the South American surgeons attending. In South America, as in Boston, Cleveland and indeed most neurosurgical centres at that time, they were still clinging to the Gairdner concept that "all syringomyelia was hydromyelia" and accordingly designed complicated, risky, expensive and worthless operative procedures, including a plug of muscle at the obex of the 4th ventricle. Later, water-soluble contrast and then spinal MRI disproved these speculative notions and confirmed my pathological observations and simplified therapy. ${ }^{1}$

The late Andre Barbeau, a friend of mine from Montreal (and incidentally a passionate separatist) presented his very early attempts to use dopaminergic drugs to treat Parkinson's Disease. This was a logical sequel to the demonstration by Olle Hornykiewitz that dopamine was seriously reduced in the basal ganglia of patients who died from Parkinson's Disease. By a mere chance, as no one knew which was better as a therapeutic replacement the levo or the dextro form, Barbeau tested the dextro form. Accordingly the Nobel Award went to Cotsiaz in New York City who used the levo preparation (L-Dopa). Hornykiewitz' fundamental observations were absolutely vital to all therapeutic studies and later success but found him overlooked by the Nobel Committee.

We were introduced to the poverty of Lima by the Canadian ambassador (Freeman Tovell) and his compassionate and beautiful Spanish-born wife. The hospital's infectious diseases were housed and cared for in a tent on the hospital grounds. Rain and cold are such rarities in Lima that with a few fans a tent was adequate "public ward" accommodation. There we saw fresh cases of polio (no refrigeration to house available vaccines), TB of bones (no compulsory pasteurization of milk which eliminates the risk of the bovine strain of tuberculosis with its predilection to bones and joints as well as brucellosis) and one patient with Typhoid fever (again no available vaccine storage). From the handful of Canadians at the meeting, Barbeau and I collected sufficient funds from ourselves and colleagues to purchase a modern refrigerator for the hospital.

After the Congress we had to choose between going to the Inca ruins at Machu Pichu, which was a well-organized tourist route, or flying over the Andes to Iquitos the beginning of the second-longest river on earth and then travelling down the Amazon River by stages in a float plane. We chose the latter. Our guide in Iquitos was an expatriate German (Schmitt) whose military demeanor and the fact that he had two pistols on his belt, suggested to Kay and me that he may have been hiding from his wicked (Nazi) past. "Why 2 revolvers?" ("The jungle, she has many unfriendly faces"). Iquitos was nothing if not remote and well off civilization's pathways. All the houses were on stilts against flooding monsoons. Stinking sewage was running down the middle of the street to empty into the great river. Schmitt's domestic pet was a young jaguar that followed us through the jungle trails but snarled when we got too close to his comfort line. Here we encountered our first howler monkeys who did not like our presence and said so quite loudly as did many members of the parrot family and several noisy species of Toucans (Figure 1). A Canadian forest is quiet by comparison.

With a 50 horse-power US built outboard attached to a big dug-out canoe, our guide took us down river to two ports of call. The first was a pre-arranged rendezvous with several male members of a jungle tribe each wearing straw skirts and each carrying a blow-gun. They demonstrated their ability to use their implements to kill parrots in a flock near the top of a forest giant. This contrived visit to a primitive tribe was rewarded by Schmitt

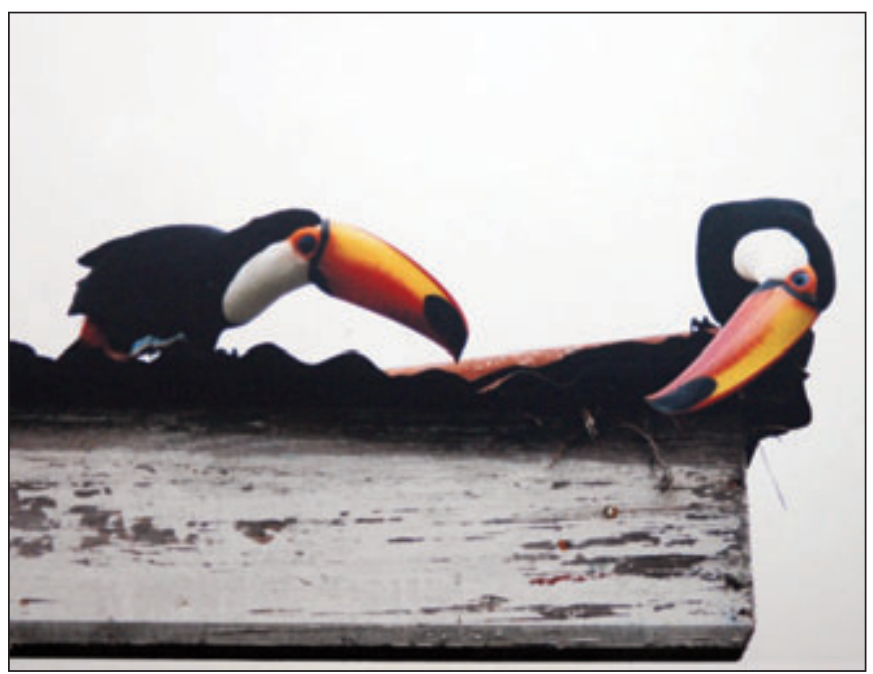

Figure 1: Two chestnut-mandible toucans picking insects under the shingles of an old shed at Iquitos, Peru. 


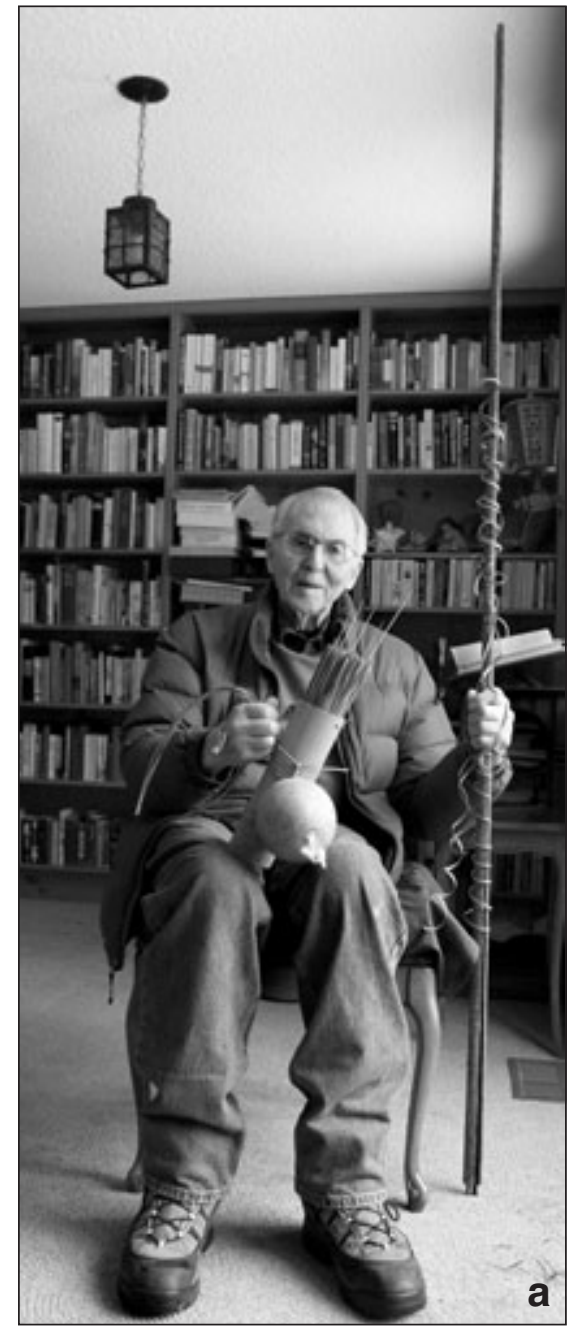

a

Figure 2: a) The author holding the blow-gun, quiver of darts and gourd of cotton to serve as a baffle wrapped around the base of a dart. All acquired from a native along the Amazon River. Note: After 45 years, the rubber covering of the gun has deteriorated. b) Dugout canoe paddles from the Amazon at Manaus.

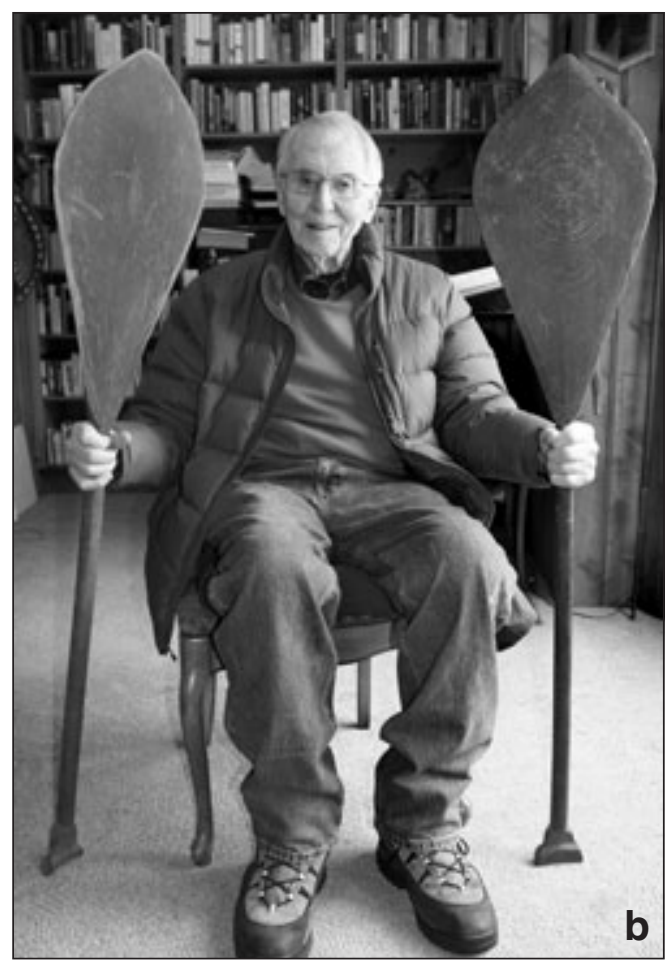

with a bottle of whiskey received with smiles and murmurs: shades of the English fur-traders and the Iroquois! Before they slid back into the dense jungle, Kay and I shook them all by the hand. Impulsively, I bought for the price suggested by our guide one blow-gun plus the quiver of darts and the dried gourd containing the cotton packing to be placed so as to encircle the proximal stem of each chosen dart (Figure 2a). All these primitive instruments are on the wall of my study and overlook my computer, printer, telephone, cell-phone, radio, camera, dictionaries and crowded bookshelves. Quite a visible contrast to the instruments belonging to and essential to the support of two very disparate human civilizations.

The conundrum presented by the transport home of an eightfoot blow-gun and quiver of darts from Iquitos to Toronto was settled by the second down-river visit of the day. We got out unto a well-made dock and were met by a London Ontario, Canadian Christian missionary. He was holding a pair of the smallest species of monkeys in the Amazon region (smallest in the entire world according to him). Their name escapes me. He could almost close his fist with one in the palm of his hand. Each was only a little bigger than a bullfrog. The house looked neat, painted, with the grass cut both front and back. My question to him was why cut all this grass here in the jungle? "Anacondas, boa constrictors and other snakes are common and we can see them before they see us!" I did not ask if they merely chased them or used a machete to deal with them. Nor did I ask if they used herbicides. Also I did not ask what Christian sect they were peddling. Previous experience had taught me that I would then be grilled about the state of my own soul. Probably their little group (all Canadians, including a graduate nurse) were doing more good than harm. In return for taking charge of my weaponry and delivering it to London, I made a moderate additional contribution to their treasury and Kay said a few kind words of thanks and expressed a hope that they would flourish. There they were in as isolated a spot as the New World offers. Kay's timidity about dugout canoes was gradually reducing (Figure 2b).

We went in stages by float-plane from Iquitos in Peru, to Manaus in Brazil, refueling from drums of aviation fuel in containers left beside docks along the river. We were taken 
ashore in dugouts quite a lot less likely to tip than our cedar or metal canoes. In those early days, dense jungle of forest giants lined the shores and was a glorious and never-ending sight wherever we looked. We took our meals of native foods at small pre-arranged dwellings at the fuel stops. The plane was not airconditioned. The co-pilot closed the two forward vents as we were about to hit the water. I was assigned to do the same for the two rearmost vents that would be below the water-line. The plan was to keep out the piranha-infested river water and I was exceptionally diligent with my assigned task!

Manaus, midway between Iquitos and Belem at the main mouth of the river was the first place where we saw areas of deliberate forest burning. Manaus had been the world's capital for native rubber. In those days it flourished and could afford a huge Opera House that has since been restored inside and out, painted etc. Its remoteness persists but the Opera House remains a national treasure in an emerging great power. The Market Square down by the river was preparing its stalls for the next day but was jammed with at least 200 black vultures squawking and fighting over morsels of food. Collectively they stank. In the suburbs to the south was evidence of charred forests, huge Brazil-nut trees with the nuts inside containers the size of and more than the weight of coconuts. Barefoot boys were often under a similar tree as they chased their soccer ball on a sandy pitch. Their enthusiasm for soccer overcame any worry about the dropping of these natural missiles. A Brazil-nut case reposes still in my curio cabinet at my home at King.

As part of our "Green-Hell" tour from Manaus we were taken in a dugout up a nearby tributary (the Negro River) to a small lake. The main features were many cayman (freshwater crocodiles) and abundant water-lilies (Victoria lily) with leaves of an average of four feet in diameter (unique in the world for size, not a few reaching six feet in diameter.) They bore easily the weight of a pair of northern jacanas with their three young. (Jacanas are close relatives of our marsh rails but with exceptionally long toes). We fished for piranhas. When hooked

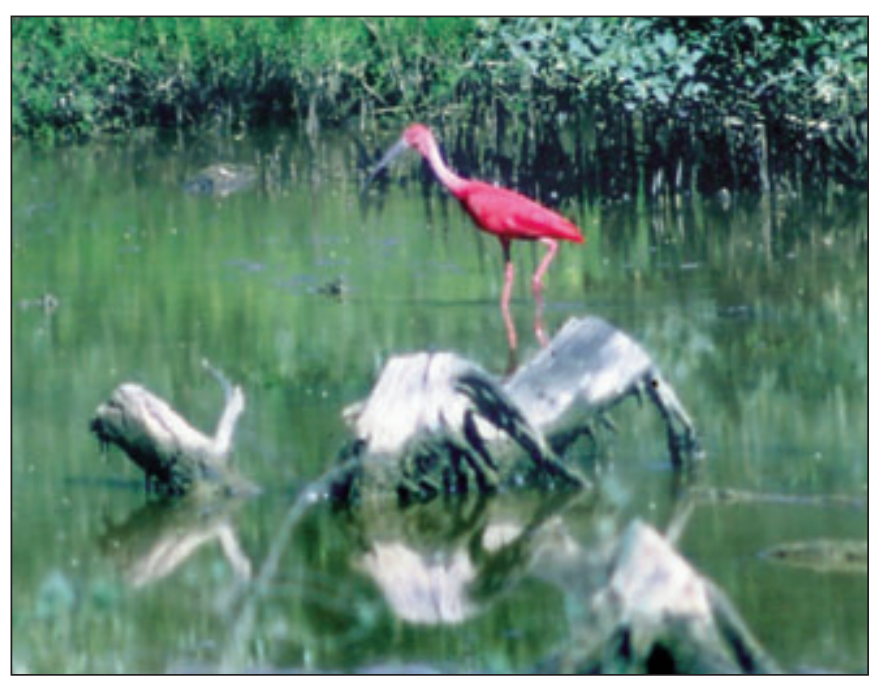

Figure 3: The resplendent scarlet ibis of Tobago. they had to be quickly brought into the canoe before they were attacked by the other crowd of their cannibalistic companions. The scent of blood drove them to madness.

In a bigger plane we left on a Sunday for Belem, the old city on the main mouth of the Amazon. I checked in for our morning flight, only to be told in a haughty manner that it had been cancelled. "When is the next one?" "Friday" he told us in such a voice as to imply "What did you think? Don't you foreigners know anything?" The next flight out of Belem was Thursday and it was to Tobago. He said it was not guaranteed yet that there would be a Friday flight. Belem was anything but an aviation hub! We spent the next days in the National Park at Belem named after Darwin's rival Wallace. Here we saw a tapir and met a Rockefeller biologist who was tending by jeep to a scattering of monkeys up in cages so that he could detect what parasites appeared in their blood samples from the bites of local mosquitoes. It was a particular challenge to take blood samples while perched atop a ladder. Plainly the life of a biologist could be as challenging as that of a neurologist!

In our two-day lay-over in Tobago, we managed to squeeze in a guided tour by Peterborough canoe of the Caroni Swamp, the home of most of the world's gorgeous scarlet ibises (Figure 3).

Two great military men, Bolivar and San Martin liberated the larger countries of South America from the greed and ruthlessness of their particular monsters of colonialism. Unhappily, after their victories, these great military men left a vacuum in civil government that has been fought over frequently ever since by the frequently corrupt exploiters of their natural treasures. This has usually been to the detriment of the indigenous populations and original inhabitants of these vast expanses of our earth. The United States, Britain and France took what they wanted mainly from Mexico and North America. In South and Central America, having destroyed their emerging civilizations, the Spanish and Portuguese tolerated little "insubordination" and through their armies and clergy, encouraged overpopulation and set the stage for mass poverty. Commonly bishops and priests sided with the armed forces who proceeded to topple most of the larval democracies and ruled with all the cruelty needed to stay in power and amass personal fortunes.

A good example of the continuing battles occurred within recent years: the takeover of the presidency in Brazil in the 1970's by a triumvirate of Generals. They were much feared and apparently had a lot of jealousy for personal power. One of this triumvirate complicated matters by having a major stroke. This disaster was followed by a series of minor cerebral vascular events. It became a matter of consequence that his diminishing judgment be accepted as incompatible with his office. His future outlook and role in government had to be clarified. None of the medical staff at the Rio de Janeiro Veterans' Hospital wished to run the apparent risk of "making the call" and declaring such a powerful figure incompetent. Supposing he were to miraculously recover? At the time of his latest event, my wife and I were guests of the Brazilian Neurological Society meeting in Goiania, near to the centre of Brazil and about three and a half hours north of Rio by air. I was invited to see the ailing General. The Brazilian plane that awaited us was designed for a few hundred troops but had only Kay and me and a crew of seven. The solicitous crew were disappointed that we ate only once and 


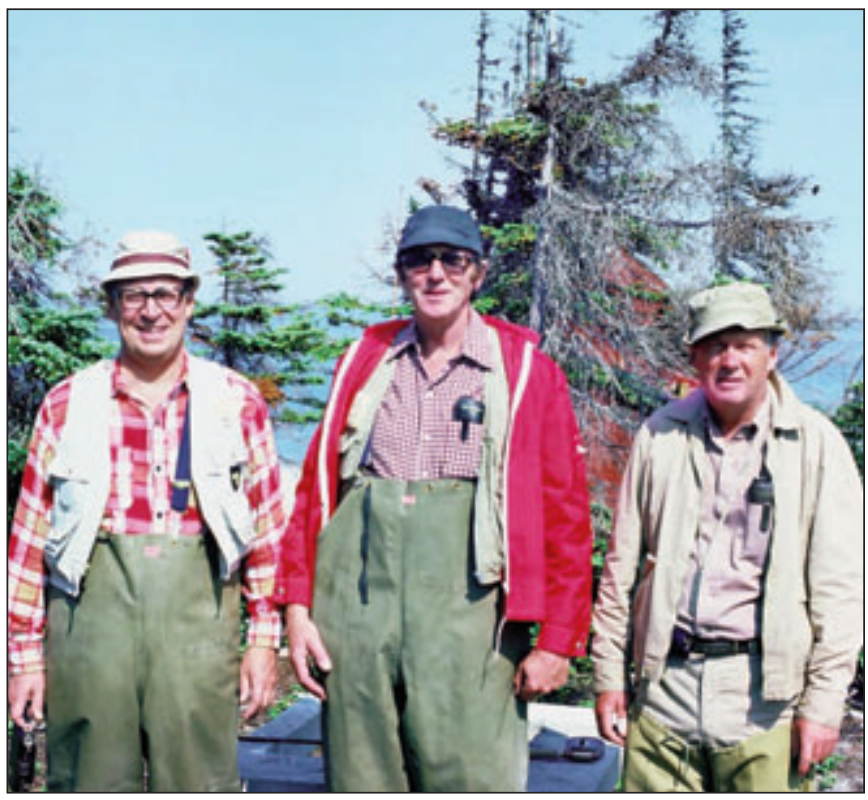

Figure 4: Charles Drake (left), the world's leading aneurysm surgeon, on a Labrador fishing excursion with the author (HJMB, centre) and Dr. Ramsay Gunton, Professor of Medicine at University of Western Ontario.

shared two glasses of wine between us. At the Rio airport we taxied to an area where two big limousines awaited. Standing beside one was a large man and beside the other was a fashionably-dressed and smiling lady. To Kay I said "the beautiful lady is awaiting me, Brazillian-style!" But of course she was a PR person from the foreign office detailed to show Kay around Rio. I went with the obese one who butted his cigarette and introduced himself as the physician, Chief-of-Staff at the Veterans' Hospital. When we entered the former General's room the nurses were changing his freshly wet and soiled sheets.

He presented a text-book picture of vascular dementia, out of touch with his surroundings and beyond all hope of useful recovery. Confirmatory testing was scarcely needed but was available in a series of CT brain scans. I described on his chart my frank thoughts about the hopelessness of his condition, advised palliative care and an obligatory retirement from any intellectual demands. Upon returning home I sent a more legible but equally gloomy pessimistic report to my host in Sao Paulo who had requested my written thoughts. We were entertained that evening in Rio, to dinner at an expensive restaurant overlooking the Copacabana Beach by the patient's soft-spoken son. He was a rancher and two years before had accompanied his neighbor-rancher to London, Ontario so that Charles Drake (Figure 4) might successfully clip his basilar artery aneurysm. Jet engines shrink our world!

Our final visit to Brazil ended at the Veteran's Hospital described above. Before the Society meeting, we had been to the Matto Grosso in the huge swampland (known as the Pantanal) in the far west reaches of Brazil, adjoining Bolivia and Paraguay, with the Paraguay River between. My friend, the late Professor Roberto Milerana, head of neurology in Sao Paulo, had friends

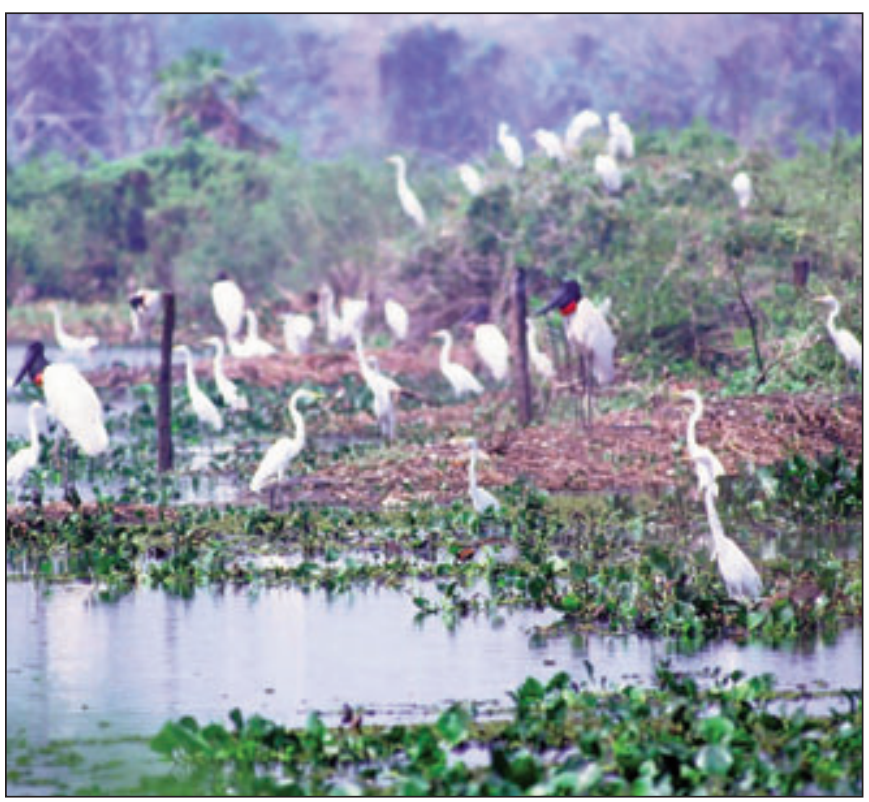

Figure 5: A marsh alongside the Paraguay River with egrets, spoonbills, ibises and Maribu storks all resting quietly. Our host's pistol shot raised a veritable cloud of marsh birds.

with a huge ranch in this remote area, accessible largely by ranch planes. One day from a jeep, we watched a huge boa constrictor slither across the dirt road ahead. Suddenly the driver leaped out and with his machete cut up the great snake! A dreadful experience and quite unnecessary. On the same day we watched four jaguars running across a nearby hill - a record number for any in the group. Had they been within pistol range I do not doubt but that they would have been targets. Our host carried a pistol and to demonstrate the richness of swamp life (Figure 5), he took us on a road overlooking a huge marsh, fired his gun and a veritable cloud of egrets, spoonbills and jabirus etc. flew up a unique addition to the art of bird-finding! On my morning walks my trousers were heavily stained with soot, where I had walked through recently burned forest. Primeval tropical forest was being converted to pastureland to cope with the North American demand for hamburger meat. Another "first" was a 45minute motor-boat trip down the Paraguay River. We counted 40 cayman basking in the sun at the edge. The hope is that some of these wonders will last.

\section{REFERENCE}

1. Barnett HJM, Foster JB, Hudgson P. Syringomyelia. Vol. I. In: "Major problems in neurology". London, England: W.B. Saunders; 1971. 